\title{
Memorizing Shakespeare
}

\section{Karen Newman}

\section{(2) OpenEdition \\ Journals}

Electronic version

URL: http://journals.openedition.org/shakespeare/3905

DOI: 10.4000/shakespeare.3905

ISSN: 2271-6424

\section{Publisher}

Société Française Shakespeare

\section{Electronic reference}

Karen Newman, "Memorizing Shakespeare ", Actes des congrès de la Société française Shakespeare [Online], 35 | 2017, Online since 12 May 2017, connection on 20 April 2019. URL : http:// journals.openedition.org/shakespeare/3905; DOI : 10.4000/shakespeare.3905

This text was automatically generated on 20 April 2019.

(C) SFS 


\title{
Memorizing Shakespeare
}

\author{
Karen Newman
}

For this invention [writing/letters] will produce forgetfulness in the minds of those who learn to use it, because they will not practice their memory. They will trust to the external written characters and not remember of themselves. Plato, Phaedrus.

1 In their study of erasable table books, the collective authors of "Hamlet's Tables and the Technologies of Writing in Renaissance England" note the prominent role books play in Hamlet and declare that "perhaps the most important book in the play, both figuratively and literally, is that of memory." ${ }^{1}$ As they go on to observe, there is paradox in the notion of erasable tables as an aide-mémoire since they serve both to record, for the purpose of remembering, and to materialize forgetting. The reading of Hamlet which follows their material description of erasable tables, of almanacs with erasable leaves, of pins and pens, emphasizes forgetting, the mutability of the body and of memory: "the play moves relentlessly away from the kind of records that, stored in a library, might protect the remembrance of the old king," Their essay ends evoking pathos: the ghost of Hamlet's father, we are told, "after changing into his nightgown, suffers an even more ignominious fate than does his murderous brother: he simply fades away, erased from the tables of memory". 2

Recent work on memory has focused on the social, cultural, cognitive and political dynamics of memory and forgetting, but particularly on trauma, "post-memory," haunting, PTSD (Post-Traumatic Stress Disorder). Yet the pre-modern world was more sanguine about memory than this view of Hamlet, or of memory studies, allows, for if in fact at the end of the play the ghost is gone, forgotten, Hamlet the play remains: its story is repeatedly told and retold, thus enacting Hamlet's injunction to Horatio at play's end. And Hamlet is repeatedly produced and remembered in the passages and commonplaces students, teachers, readers and playgoers retain in memory: "Remember me," "Frailty thy name is woman," "Neither a borrower nor a lender be," "To be or not to be, that is the question." 
3 Over the last decade, scholars have studied the various forms of mediation whereby Shakespeare has been transmitted: the history of print, publishing and editorial practices; adaptation, rewriting and translation; film; knock-offs and tie-ins, on-line forums, blogs and vlogs, all historically specific practices that have shaped the interpretation and reception of the plays and poems. Here I want to consider another form of transmission: the practice of memorization. The Phaedrus from which I take my epigraph has been read by Derrida and others for its presentation of the binary, speech/writing, and famously, for the difficulties posed by the translation of pharmakon, a word that famously means both "remedy" and "poison." But in Plato's dialogue, Socrates is concerned with memory. Writing for Socrates, as for many intellectuals and thinkers in the ancient world and at least through the Middle Ages, was a reminder of what one knew already, a servant to memory. How did the practice of memorizing Shakespeare come about and what was its function? Why did memorization of Shakespeare become a historically specific practice of cultural mediation?

$4 \quad$ Mary Carruthers begins her fine book The Book of Memory with a discussion of Thomas Aquinas's techniques of composition. Aquinas was renowned throughout the Middle Ages and into the Renaissance for his memory: he is reported to have dictated "as if a great torrent of truth were pouring into him from God. Nor did he seem to be searching for things as yet unknown to him; he seemed simply to let his memory pour out its treasures."3 Myriad texts were apparently filed in his memory, for use whenever he needed them. In this description of Aquinas's memory, we get a standard metaphor for memorizing to which I will return, the metaphor of treasure. Memory, as Carruthers goes on to point out, was not only a part of composition and litteratura, the noblest of the five divisions of ancient and medieval rhetoric; it also "built character, judgment, citizenship and piety." Cicero, Quintilian, and the Renaissance humanists reiterate such claims as do later educational theorists, and as do the writers and compilers of rhetorics and readers in Ireland, England and the United States during the heyday of poetry memorization in the nineteenth century. Memoria, in Carruthers' words, also "signifies the process by which a work of literature becomes institutionalized - internalized within the language and pedagogy of a group". ${ }^{4}$ In what follows, in addition to surveying the tradition of memorizing Shakespeare, I will also speculate on the role memorization played in his canonization.

5 Shakespeare has been memorized, of course, by actors since the plays were first produced. From the late fifteenth-century on, humanists and teachers used drama for both teaching and learning. "Playacting occasioned learning in language, diction, gesture, attitude and sententiae", 5 in schools and universities, and in the Renaissance academies established in Italy and elsewhere in Europe by humanists and their patrons interested in sharing ancient texts, reviving the ancient theatre and studying classical antiquity. Theatrical performance, and the memorizing of parts, was an important aspect of the humanist intellectual enterprise and of humanist education all over Europe.

6 While plays were performed in schools, colleges and universities initially in Latin, with a view toward improving pupils' language and oratorical skills, by the middle of the sixteenth-century, plays were increasingly performed in the vernacular. In Siena, for example, the Academy known as the Intronati collaborated in the writing and performance of plays the most famous of which is Gl'Ingannati, first performed in 1532, one of the earliest vernacular comedies of cross dressing and mistaken identity. Widely imitated and translated, a version of this precursor to Shakespeare's Twelfth Night was 
performed at the University of Cambridge, England already in 1546-1547. Theatricals were produced for many special occasions before mixed audiences made up not only of members of colleges and academies themselves, but also royal and aristocratic invitees and general audiences made up from the surrounding population. School productions were performed not only in college buildings, but also at court and in public squares. ${ }^{6}$ Many of the earliest English Renaissance plays, Ralph Roister Doister modeled on the Latin comic playwright Plautus's Braggart Soldier and written by Nicholas Udall, headmaster of Eton, and Gammer Gurton's Needle, written at Cambridge by one Mr. S, were written for performance in schools. Gammer Gurton's Needle, as we learn from the 1575 titlepage of an early printed edition, was "played on Stage, not longe ago in Christes Colledge in Cambridge." As Alan Nelson has shown, more performances of plays and other dramatic activities are recorded at Cambridge in the mid-sixteenth-century than in any other town in England, including London. ${ }^{7}$

7 The performance of plays by young scholars was intended to teach moral lessons and to improve oratorical skills. Plays that elaborated on scripture were enormously popular not only in England, but in schools and colleges all over Europe. The Scot George Buchanan, a pre-eminent neo-Latinist of the period, taught at the renowned College of Guyenne in Bordeaux, a college with a strong dramatic tradition that included among its dramatists and actors not only Buchanan himself, but Joseph Scaliger and Montaigne. Buchanan believed that "once action is brought to life with speech and breath, it makes a stronger impression on the senses than bare moral lessons, and influences the mind more easily. And where it has penetrated, it clings more firmly, and virtually takes root". ${ }^{8}$ Even girls had the opportunity to perform plays at school: famously Racine wrote both Esther and Athalie for performance before Louis XIV by the Demoiselles of the boarding school begun by his second wife, Madame de Maintenon, at St. Cyr. Drama was also an important part of the curriculum of the many Jesuit colleges founded in the sixteenth century, including those in what is now the north of France that were established to educate the boys and young men of recusant English families. It is estimated that between 1650 and 1700 there were some 500 continental Jesuit colleges performing at least two plays annually. JeanChristophe Mayer has shown that the recently discovered First Folio found in the library at Saint-Omer bears marks indicating its use for dramatic performance at the college there. ${ }^{9}$ In England, choir-boys at the royal chapels of Westminster, Windsor and St. Paul's were trained not only in music, but also as young actors who performed at court before the Queen. As is well-known, the Inns at Court, ostensibly for the training of lawyers, were centers of intellectual and literary activity where young men congregated to pursue distinction, pleasure and advancement. In his Characterisimi (1631), Francis Lenton claims young men of the inns showed a marked preference for "Shakespeare's plaies instead of my Lord Coke," (sig. F4) the well-known early modern jurist. In fact, the Inns were a center of theatrical performance, particularly during Christmas festivities, and at Carnival as we know from the Middle Temple law student John Manningham's famous account in his diary, that on February 2, 1602 "at our feast we had a play called Twelfth Night, or What you Will." School performance of Shakespeare remained-and remains - an important pedagogic practice, but in what follows I turn to the practice of memorizing discrete passages from Shakespeare in the schools, in clubs and reading groups, among a broad swath of the population in England and its former colonies, including America, from the late 18th century until the middle of the 20th century when the pedagogic practice of memorization went out of fashion. Such memorizing is carefully distinguished from acting and dramatic performance in the manuals, readers and handbooks that 
promoted memorizing selections from choice authors, but avoiding the taint of dramatic performance.

8 That there was a popular tradition of such memorization is not in doubt: we have countless examples, some of which are familiar..$^{10}$ Perhaps the most famous example is Cole Porter's comic account of this practice and its uses and effects in the musical based on The Taming of the Shrew, Kiss Me Kate. Even as late as the early 1950's, memorizing Shakespeare would seem to have been a widespread school practice, and according to Porter's lyrics, it would also seem to be an effective strategy of seduction. To win a girl's heart and "start 'em simply ravin' / Is the poet people call The Bard of Stratford upon Avon." Next comes the well-known chorus:

Brush up your Shakespeare,

Start quoting him now.

Brush up your Shakespeare

And the women you will wow.

Porter's lyrics continue:

Just declaim a few lines from Othella
And they'll think you're a hell of a fella
If your blonde won't respond when you flatter 'er
Tell her what Tony told Cleopatterer
If she fights when her clothes you are mussing
What are clothes? Much ado about nussing
Brush up your Shakespeare
And they'll all kow-tow.

10 Porter deploys puns we have come to associate with recent work in the history of sexuality - "If she says your behavior is heinous/ Kick her right in the Coriolanus." The musical's lyrics are often salacious and presume that quoting Shakespeare has a sexually affective power: "Just recite an occasional sonnet /And your lap'll have honey upon it./ When your baby is pleading for pleasure/ Let her sample your Measure for Measure/ Brush up your Shakespeare And they'll all kow-tow...." To brush up, of course, means to revive or refresh one's acquaintance with something, something it is presumed you already know. In the musical, you may remember, two gangsters sing this song, with its low brow dialectical usages, thus insisting that memorizing Shakespeare was a popular school practice, not an elite one. The two thugs in Porter's musical would have learned their Shakespeare in the schools where memorizing passages and "memory gems" was a widespread practice. And their stated plans to use that knowledge to seduce is a far cry from the moralizing claims so often made on behalf of memorizing. In Dodsley's wellknown Preceptor, a famous and long-employed text "containing a general course of education," for example, passages to be memorized from the poets, including Shakespeare, insured a mind ready for use "by its being stor'd with Variety of good Principles, sure Rules, and happy Expedients, reposed in the Memory, and ready upon all Occasions to be produced and employed in Practice". ${ }^{11}$

11 Memorizing has a long pedagogical history and has long provoked debate. Cicero, of course, notes its importance in De Oratore where the aspiring orator is exhorted, to learn passages by heart to exercise his memory and to provide himself with a store of materials for use in composition and declamation. Frances Yates and more recently, Lina Bolzoni, have traced the elaborate system of rooms and places to train the memory from ancient times into the early modern period. With the advent of printing, Yates claims, not unlike Plato's Egyptian king in the epigraph from Phaedrus, memory declined and many of the 
practices associated with the arts of memory, such as the schematic layout of manuscripts designed to aid memory, began to disappear as printed copies became plentiful. ${ }^{12}$ But as Carruthers and others have pointed out, books are memory's extension: just as remembering was conceived of as writing on the tables of the mind, so writing was regarded as an activity of remembering, and textual notes, including the commas and other editorial signs that mark sententiae to be remembered, a branch of memory. ${ }^{13}$ Though the humanists' study of Quintilian may have shifted memory away from the more schematic places and images to "study, order and care," as Yates claims, quoting Quintilian, Quintilian nevertheless still recommends memorization. And as Paul Grendler, Lisa Jardine and Anthony Grafton have shown in their studies of early modern pedagogical practice, memorizing played an important role in Renaissance education. Jardine and Grafton, in fact, show the gap between humanist theory concerning the "civilizing" power of knowledge of Latin and classical authors and actual classroom practice characterized by the "ruthless drilling" of mnemonic verses and jingles for teaching grammar and texts by rote. ${ }^{14}$ Classical authors in the humanist curriculum, they show, were treated in a utilitarian and cursory way or epitomized in collections of sententiae. Grafton and Jardine thus contend that humanist claims about the formation of character through education are unconvincing in themselves and were discredited by actual classroom practice.

12 Yet as Carruthers argues, memory is a cultural complex of institutionalized practices far from what we term mere rote learning. Instead, as she insists, "memoria places rote in the service of creative thought." ${ }^{15}$ She lays out the distinction between res and verbum, between the memory for matter - not just things or objects, but ideas, opinions, matter that can be called upon for composition in writing or speaking, and word for word repetition, memorizing verbatim particularly associated with school-room exercises in which children train their memories by rote. These two views of memory have been described and debated from the time of the ancients and into the early modern period, and they continue even today - those who argue on behalf of memorization and see the training of memory as productive, and those who see it as mere rote learning that in fact inhibits understanding, as "merely" reproductive.

13 We see this debate laid out in the letters that become Locke's Some Thoughts Concerning Education. There he objects to the practice of forcing students "to learn by heart great Parcels of the [ancient] Authors." ${ }^{16}$ Such learning is nothing more, Locke opines, than "the just Furniture of a Pedant" and "nothing is less becoming a Gentleman." ${ }^{17}$ For Locke what matters is the Matter. Yet when "the Matter is worth Remembrance," Locke admits "it may not be amiss to lodge it in the Minds of young Scholars." ${ }^{18}$ Locke calls learning lessons by heart an "old Custom," and wants to insure that boys understand what they learn. ${ }^{19}$ Yet like Cicero and Quintilian before him, he too wants them to repeat it, and know how to call upon it - otherwise, he objects, the lesson once said by rote is merely "delivered up again to Oblivion." ${ }^{20}$ Locke is concerned specifically with the place of ancient languages - Latin and Greek - in education and with the Renaissance practice of having schoolboys memorize in order to express themselves in Latin, orally and in writing, which was the student's main task before 1700. If by the end of the seventeenth century evidence suggests there begins to be a shift to English from Latin, at least in some classrooms where English is increasingly important for a rising middle class engaged in business and trade, what is astonishing is how much was still got by heart. Throughout the eighteenth century, as Ian Michael has shown in his important study, The Teaching of 
English, popularly adopted grammars, both Latin and English, provide directions for memorizing to both masters and students; John Collyer's 1735 grammar, for example, instructs that "Only the large Print is to be got without Book," that is, memorized, but the "large Print" alone requires memorizing more than 10,000 words; James Gough's 1754 text requires 5600, and Alexander Miller's widely used American English grammar would require memorizing some 11,000 words. At least ten other 18th-century grammars make similar demands; such memorizing remained ordinary practice until well into the nineteenth century in both England and the United States. As Michael observes, "learning by heart, in all subjects, was a useful form of pedagogic and, it was hoped, mental discipline ... by learning in childhood you had a "store" on which to draw". ${ }^{21}$ By the end of the18th-century, partly in response to the rise of the elocution movement associated with John "Orator" Henley and Thomas Sheridan, the practice of memorizing the best vernacular authors seems to have been well-established.

When does Shakespeare become one such author? Alexander Gill, the high-master of St. Paul's in the early 17th century, publishes his Logonomia Anglica in 1619 and again in 1621; his text includes 7 chapters on figurative syntax illustrated by quotations from Spenser, Sidney, Harrington, Daniel, Wither, and Stanyhurst's Aeneid, but no Shakespeare; Abraham Fraunce's Lawiers Logike quotes extensively from Spenser and Sidney; Peter Stallybrass and Zach Lesser have recently pointed out the wealth of quotations from Shakespeare and other vernacular writers in Bodenham's Bel-vedere, a text to which I will return. In 1657 Joshua Poole's The English Parnassus includes some Shakespeare. But for much of the eighteenth century, Milton is more often quoted than Shakespeare, which Michael explains by suggesting that dramatic verse was excluded altogether on moral grounds. And though it might be tempting to make judgments about the relative canonicity of Shakespeare and Milton in the period based on the frequency of such quotation, we would do well to remember William St. Clair's important work on intellectual property that shows the clamp down after 1600 on anthologies, abridgements and adaptations, the most important means by which texts and ideas are diffused, especially to the less well-educated and economically disadvantaged. Michael claims that an increase in the inclusion of literary excerpts in texts directed at both ordinary children and those in educated homes shows a change of attitude about the worth of literature in the 1770s. But in fact, the change is more likely related to the end of perpetual copyright, for it was the cartels of what St. Clair terms the "high monopoly period," and specifically the Tonsons, who commissioned and published expensive Shakespeare editions throughout the eighteenth century. The change Michael notices in the 1770s is a result not so much of changing attitudes toward education as the end of perpetual copyright in 1774. In addressing the House of Lords at the time of the copyright disputes, Lord Camden asserted that if the London publishers had their way, "All our Learning will be locked up in the Hands of the Tonsons." ${ }^{22}$

But two exceptional mid-eighteenth-century texts stand out: the printer Robert Dodsley's widely used Preceptor (1748) and William Dodd's anthology Beauties of Shakespear. The Preceptor offers a range of Shakespearean extracts - from Henry IV pts. 1,2; Henry V, Henry VIII, Julius Caesar, Timon, and one of the rare passages taken from the comedies, not surprisingly Jacques' “All the world's a stage" from As You Like It. As Dodsley's recent biographer points out The Preceptor "established a model curriculum heavily reliant on excerpts from the best contemporary authors," especially Shakespeare. ${ }^{23}$ In 1752, the Anglican preacher William Dodd published the only eighteenth-century Shakespeare 
anthology, Beauties of Shakespeare, which includes an enormous range of passages from the plays, each with a moralizing heading - on chastity, on too ambitious love, advice of various kinds. The anthology is said to have been widely read "by many whose religious convictions would not permit them [otherwise] to read plays. " Dodd's Beauties was "constantly reprinted from 1752 to 1935" - in fact, a reprint is available on Amazon today. 24

But after 1774, Shakespeare is one of the authors most quoted in a whole spate of newly printed anthologies, collections, inexpensive editions, readers, and the so-called "Speakers" associated with the elocution movement. One of the most popular Wordsworth called it "the poetical library of our schools" - was Vicesimus Knox's series of Elegant Extracts in Verse which appeared in various editions between 1778 and 1794. Knox acknowledged that it was common to declaim against loading the memory, but argued that boys' memories were and called for the reading and memorizing of a slate of authors: Demosthenes, Plato, Homer, Cicero, Livy, Virgil, Milton, Shakespeare, Pope and Addison in chapter titles such as "Classics by Heart." In England there is William Enfield's The Speaker, said to be the most widely used of all the anthologies with 38 selections from Shakespeare, one quarter of the total; there is John Walker's Elements of Elocution and a burgeoning market in school readers that first develops in Ireland, where fear of the island's perceived hostile population and "alien religion were menacing enough to loosen purse strings. ${ }^{25}$ In her recent book Heart Beats on the practice of memorizing poetry in the elementary or primary schools of late nineteenth-century England and America, Catherine Robson notes in passing the popularity of memorizing the most unexpected passages of Shakespeare. ${ }^{26}$ She records a Sussex man's memory of his state education at Harting Combe, where eight-year-olds in Standard II had to learn by heart the scene from King John where Arthur pleads with Hubert not to put out his eyes. ${ }^{27}$ She goes on to observe that this particular teacher was apparently not "unusually sadistic" since an article from The Teachers' Aid in 1887 advised teachers to think carefully about the choice of passage for pupils to perform in their examinations and urges its readers not to "select hackneyed ones. ... [such as] 'Mark Anthony's oration' from Julius Caesar, and 'Heat me these irons hot'. ${ }^{28}$

British secular readers were also plundered for the American market as Meredith McGill's important work on the culture of reprinting in the United States has shown. Abraham Lincoln is believed to have learned his Shakespeare, which he read and quoted throughout his life, initially from the Scot William Scott's Lessons in Elocution. And if we bear in mind as well the remarkable distribution of British books and authors unconstrained by international copyright agreements throughout the nineteenth century we can see how Shakespeare became so widely read that Tocqueville famously claimed that "There is hardly a pioneer's hut that does not contain a few odd volumes of Shakespeare". ${ }^{29}$ And in addition to inexpensive editions, there were the popular American readers, McGuffey's 5th and 6th Eclectic that include selections from Shakespeare, and the indigenous collections with titles like Gleanings, A Casket of Thought Gems, Memory Gems, Best Memory Gems, Memory Gems Graded because "Youth is the golden period for storing the mind." As John Neitz observes in his study of American secondary school textbooks, "even today many older people, who studied the McGuffey books, can recite these selections". ${ }^{30}$

The practice of memorizing Shakespeare, from the elocution textbooks and vernacular collections of the second half of the eighteenth century, through the anthologies and 
readers of the nineteenth century and well into the twentieth, played a significant role in institutionalizing Shakespeare, not only in the schools, but in the culture at large. In their study of commonplacing, John Bodenham's Bel-vedere, and Q1 Hamlet, Zachary Lesser and Peter Stallybrass conclude that "a broad range of readers, professional dramatists, and London stationers used commonplace markers as a way to elevate their playbooks and to indicate their suitability as serious reading matter". ${ }^{31}$ From the practice of commonplacing play texts, they argue that Q1 Hamlet is a "literary publication." But perhaps the practice of commonplacing, in addition to proving the suitability of plays as "serious reading matter," may mark particular lines as worthy of committing to memory. The practice of commonplacing played an important role not only in the production of the popular drama as "literature," but also as a source of sententitae to be memorized. It is significant that Bodenham's Belvedere or The Garden of the Muses is reprinted, as its title page notes, "from the original edition of 1600 " in 1875 , in the heyday of what might be termed the memorization movement. Shakespeare remains "after Shakespeare" because his memorized remains produced vital connections with individuals, with communities, and with discourses, beliefs and behaviors the remains of which persist even today.

\section{NOTES}

1. Peter Stallybrass, Roger Chartier, J. Franklin Mowery, and Heather Wolfe, "Hamlet's Tables and the Technologies of Memory," Shakespeare Quarterly 55: 379-419, 2004, p. 379.

2. Idem, p. 419. The reference to old Hamlet in his nightgown is to the stage direction found only in Q1 Hamlet.

3. Mary Carruthers, The Book of Memory. A study of memory in medieval culture, Cambridge, Cambridge University Press, 2008, p. 7.

4. Idem, p. 11.

5. Kent Cartwright, Theatre and Humanism: English Drama in the Sixteenth Century, Cambridge, Cambridge University Press, 1999, p. 13-14.

6. W. H. McCabe, S. J., An Introduction to the Jesuit Theater, ed. Louis J. Oldani, S. J. St. Louis, The Institute of Jesuit Sources, 1983, p. xi.

7. Alan Nelson, Early Cambridge Theatres: University and Town Stages 1464-1720, Cambridge, Cambridge University Press, 1994.

8. From the preface to Buchanan's translation of Alcestis (1557), in George Hoffmann, Montaigne's Career. Oxford, Clarendon Press, 1998, p. 59

9. Jean-Christophe Mayer, "The Saint-Omer First Folio: Perspectives on a New Shakespearean Discovery," Cahiers Elisabéthains: A Journal of English Renaissance Studies, 87: 7-20, 2015, p. 11-18.

10. For the US, see Rubin who notes that memorizing Shakespeare was a "standard feature of the high school curriculum." (Joan Shelley Rubin, "Listen my Children: Modes and Functions of Poetry Reading in American Schools 1880-1950," Moral Problems in American Life. New Perspectives on Cultural History, eds. Karen Haltunen and Lewis Perry. Ithaca, Cornell University Press, 1998, p. 261-281, p. 264). See also her more recent Songs of Ourselves. The Uses of Poetry in America, Cambridge, Harvard University Press, 2007. On Shakespeare in America, see Lawrence W. Levine, Highbrow/Lowbrow. The Emergence of Cultural Hierarchy in America. Cambridge, Harvard University 
Press, 1988. For Britain see Richard D. Altick, The English Common Reader: A Social History of the Mass Reading Public, 1800-1900, Chicago, Chicago University Press, 1957.

11. Dodsley, The Preceptor, London, $1748, \mathrm{D} 2^{\mathrm{r}}$.

12. Frances A Yates, The Art of Memory, Chicago, University of Chicago Press, 1966, p. 124. But as William St. Clair has shown, the coming of print seems to have generated more texts rather than more copies (William. St. Clair, The Reading Nation in the Romantic Period, Cambridge, Cambridge University Press, 2004, p. 22).

13. Mary Carruthers, op. cit., p. 129.

14. Lisa Jardine and Anthony Grafton, From Humanism to the Humanities: The Institutionalizing of the Liberal Arts in Fifteenth and Sixteenth-Century Europe, Cambridge, Harvard University Press, 1987, p. 27.

15. Mary Carruthers, op. cit., p. 134.

16. John Locke, Some Thoughts Concerning Education, ed. John William Adamson, Mineloa, New York, Dover Philosophical Classics, p. 142.

17. Idem, p. 143.

18. Ibid.

19. Ibid.

20. Idem, p. 145.

21. Ian Michael, The Teaching of English: From the Sixteenth Century to 1870, Cambridge, Cambridge University Press, 1987, p. 259.

22. Quoted in Andrew Murphy, Shakespeare in Print. A History and Chronology of Shakespeare Publishing, Cambridge, Cambridge University Press, 2003, p. 13.

23. Harry M. Solomon, The Rise of Robert Dodsley: Creating the New Age of Print, Carbondale, Southern Illinois University Press, 1996, p. 127.

24. Edwin Eliott Willoughby, “A Deadly Edition of Shakespeare," Shakespeare Quarterly 5: p. 351-57, 1954, p. 351.

25. J. M. Goldstrom, The Social Content of Education 1808-1870, A Study of the Working Class School Reader in England and Ireland, Totowa, NJ, Rowman and Littlefield, 1972, rpt. 1978, p. 52.

26. In addition to Catherine Robson's Heart Beats (Princeton, Princeton University Press, 2011), see also Joan Shelley Rubin, "Listen my Children" (Rubin, Joan Shelley, "Listen my Children: Modes and Functions of Poetry Reading in American Schools 1880-1950" in Moral Problems in American Life. New Perspectives on Cultural History, eds. Karen Haltunen and Lewis Perry, Ithaca, Cornell University Press, 1998, p. 261-281).

27. W. E. Palmer, "Memories of Long Ago," unpublished autobiography, quoted in John Burnett, Destiny Obscure: Autobiographies of Childhood, Education and Family from the 1820s to the 1920s. London, Allen Lane, 1982, p. 159.

28. Catherine Robson, op. cit., p. xx.

29. Alexis de Tocqueville, Democracy in America, New York, Library of America, 2004, p. 538.

30. John A Nietz, The Evolution of American Secondary School Textbooks, Rutland, VT, Charles E. Tuttle, 1966, p. 29.

31. Zachary Lesser and Peter Stallybrass, "The First Literary Hamlet and the Commonplacing of Professional Plays," Shakespeare Quarterly 59: 371- 420, p. 410. 


\section{ABSTRACTS}

Memorizing Shakespeare in the schools has a long and venerable history. Shakespeare himself lived in a memorizing culture in which huge chunks of literature were learned by heart, and that culture survived well into the twentieth century. Memory also plays an important role in the Shakespearean canon. The passages from Shakespeare chosen for memorization teach us a great deal about the reading and interpretation of Shakespeare in different eras, at different cultural moments and in different places. In the late nineteenth and early twentieth century, for example, the most memorized speech from Shakespeare in British elementary schools was the eye-burning passage from King John. This paper will address a part of the long history of memorizing Shakespeare with special focus on the Anglo-American context.

La pratique scolaire consistant à mémoriser des passages de Shakespeare est ancienne et vénérable. Shakespeare lui-même évoluait dans une culture de la mémorisation, où l'on apprenait par cœur de larges pans de la littérature, culture qui a perduré jusque tard dans le vingtième siècle. La mémoire joue également un rôle important dans le canon shakespearien. Les passages de Shakespeare choisis pour être mémorisés nous en apprennent beaucoup sur la lecture et l'interprétation de Shakespeare à travers les âges, à des moments culturels distincts et en différents lieux. Dans les dernières années du XIXe siècle et à l'aube du XXe siècle, par exemple, le passage de Shakespeare le plus souvent choisi pour être mémorisé dans les écoles élémentaires était un extrait de King John. Le présent article envisage une partie de cette longue histoire de la mémorisation de Shakespeare en se penchant plus particulièrement sur le contexte anglo-américain.

\section{INDEX}

Mots-clés: Anthologies, Mémorisation, École, Shakespeare, Lieux communs, Manuels, Mémoire, sententiae

Keywords: Memorization, Anthologies, commonplacing, Shakespeare, Memory, School, sententiae, Textbooks

\section{AUTHOR}

\section{KAREN NEWMAN}

Department of Comparative Literature, Brown University 